\title{
Validitas Rencana Pembelajaran Semester Mata Kuliah Kimia Dasar Program Studi Pendidikan Biologi Universitas Mahaputra Muhammad Yamin
}

\author{
Afrahamiryano ${ }^{1)}$ \\ ${ }^{1)}$ Fakultas Keguruan dan Ilmu Pendidikan, Universitas Mahaputra Muhammad Yamin \\ afrahamiryano@gmail.com
}

\begin{abstract}
This research is validation study of Semester Learning Plan of Basic Chemistry. This aims to know the validity of Semester Learning Plan of Basic Chemistry from Biology Education Program of Mahaputra Muhammad Yamin University. Validation is done by using expert consideration method. Instrument used is a questionnaire that has been analyzed using descriptive statistics. Data analysis results show that validity of the designed Basic Chemistry's Semester Learning Plan is highly valid. To strengthen the results of the analysis, then performed the analysis of validity with the consideration of expert through CVR method. CVR score obtained is \pm 1 . This show that Basic Chemistry's Semester Learning Plan is feasible and relevant used in the learning process. So, the conclusion is Basic Chemistry's Semester Learning Plan is highly valid and can be used in learning process.
\end{abstract}

Keywords : Validity; Semester Learning Plan; Basic Chemistry

This is an open access article distributed under the Creative Commons 4.0 Attribution License, which permits unrestricted use, distribution, and reproduction in any medium, provided the original work is properly cited $\odot 2018$ by author and Universitas Negeri Padang.

\section{PENDAHULUAN}

Undang-Undang Nomor 12 tahun 2012 tentang perguruan tinggi pasal 35 ayat 2 menjelaskan bahwa kurikulum pendidikan dikembangkan oleh setiap perguruan tinggi dengan mengacu pada Standar Nasional Pendidikan Tinggi untuk setiap program studi yang mencakup pengembangan kecerdasan intelektual, akhlak mulia, dan keterampilan. Oleh karena itu, setiap program studi diwajibkan untuk mengembangkan sendiri kurikulumnya. Kurikulum pada perguruan tinggi ini merupakan amanah dari institusi yang secara berkelanjutan harus diperbaharui sesuai dengan tuntutan perkembangan kebutuhan dan IPTEK yang dituangkan secara jelas dalam Capaian Pembelajaran.

Pengembangan kurikulum di perguruan tinggi di atur dalam Permenristekdikti Nomor 44 tahun 2015 tentang Standar Nasional Pendidikan Tinggi (SN-DIKTI). Permenristekdikti Nomor 44 tahun 2015, pasal 1 ayat 5 menyatakan bahwa Kerangka Kualifikasi Nasional Indonesia, yang selanjutnya disingkat KKNI adalah kerangka penjenjangan kualifikasi kompetensi yang dapat menyandingkan, menyetarakan, dan mengintegrasikan antara bidang pendidikan dan bidang pelatihan kerja serta pengalaman kerja dalam rangka pemberian pengakuan kompetensi kerja sesuai dengan struktur pekerjaan di berbagai sektor.

KKNI ini sekarang ini dijadikan sebagai dasar acuan bagi pengembangan kurikulum di perguruan tinggi. Sesuai dengan amanat Peraturan Menteri Pendidikan dan Kebudayaan Republik Indonesia Nomor 73 Tahun 2013 tentang Penerapan Kerangka Kualifikasi Nasional Indonesia Bidang Pendidikan Tinggi, pasal 10 ayat 4 menjelaskan bahwa dalam menerapkan KKNI bidang pendidikan tinggi, maka setiap program studi wajib : 1) menyusun deskripsi capaian pembelajaran minimal mengacu pada KKNI; 2) menyusun kurikulum, melaksanakan, dan mengevaluasi pelaksanaan kurikulum mengacu pada KKNI; dan 3) mengembangkan sistem penjaminan mutu internal untuk memastikan terpenuhinya capaian pembelajaran program studi.

Berpedoman pada peraturan perundangundangan di atas, maka dirancanglah kurikulum untuk program studi Pendidikan Biologi Universitas Mahaputra Muhammad Yamin. Salah satu mata kuliah pada program studi Pendidikan Biologi adalah mata kuliah Kimia Dasar.

Pada kurikulum sebelumnya, mata kuliah Kimia Dasar terbagi menjadi 2 (dua), yaitu mata kuliah Kimia Dasar 1 (3 SKS) dan Kimia Dasar 2 (3 SKS). Kemudian pada awal tahun ajaran 
2016/2017 dilakukan revisi kurikulum dan terjadi pengabungan mata kuliah Kimia Dasar 1 dengan Kimia Dasar 2 menjadi mata kuliah Kimia Dasar dengan bobot 3 SKS.

Pengabungan mata kuliah ini menuntut adanya perubahan pada perangkat pembelajaran. Perubahan tersebut terjadi pada susunan Rencana Pembelajaran Semester, dimana pada kurikulum lama materi Kimia Dasar cukup padat. Namun sekarang perlu dilakukan perampingan materi dengan cara melakukan pemilihan materi-materi ajar yang dapat mendukung kompetensi lulusan sebagai calon guru biologi. Setelah itu dilanjutkan dengan perancangan Rencana Pembelajaran Semester, yang mengacu pada KKNI. Perancangan Rencana Pembelajaran Semester ini berpedoman pada Panduan Penyusunan Perangkat Pembelajaran Kemenristekdikti.

Menurut Peraturan Pemerintah Nomor 32 tahun 2013 tentang perubahan Peraturan Peraturan Pemerintah Nomor 19 tahun 2005 tentang Standar Nasional Pendidikan menjelaskan bahwa, perencanaan pembelajaran merupakan penyusunan rencana pelaksanaan pembelajaran untuk setiap muatan pembelajaran. Perencanaan yang dimaksud dalam peraturan pemerintahan ini adalah perencanaan pembelajaran harus memuat perencanaan proses pembelajaran yang disajikan dalam bentuk Rencana Pembelajaran Semester.

Kemenristekdikti (2016) menjelaskan bahwa Rencana Pembelajaran Semester adalah dokumen program pembelajaran yang dirancang untuk menghasilkan lulusan yang memiliki kemampuan sesuai Capaian Pembelajaran Lulusan (CPL) yang ditetapkan, sehingga harus dapat ditelusuri keterkaitan dan kesesuaian dengan konsep kurikulumnya.

Syafruddin (2017) menjelaskan bahwa CPL merupakan kemampuan yang diperoleh melalui internalisasi pengetahuan, sikap, keterampilan, kompetensi, dan akumulasi pengalaman kerja.

Rencana Pembelajaran Semester berfungsi sebagai acuan bagi dosen dalam pelaksanaan proses perkuliahan. Dengan adanya Rencana Pembelajaran Semester, maka proses perkuliahan dapat berlangsung secara sistematik dan terukur. Rencana Pembelajaran Semester yang digunakan haruslah valid karena perangkat pembelajaran yang valid akan memudahkan dalam mengkoordinir mahasiswa belajar agar memiliki kemampuan sesuai dengan CPL yang telah ditetapkan. Oleh karena itu, penulis tertarik untuk menguji validitas Rencana Pembelajaran Semester mata kuliah Kimia Dasar yang sudah dirancang. Pengujian validitas ini dilakukan melalui studi validitas.

Rumusan masalah dalam penelitian ini adalah bagaimana validitas Rencana Pembelajaran Semester mata kuliah Kimia Dasar program studi Pendidikan Biologi Universitas Mahaputra Muhammad Yamin?

Berdasarkan rumusan masalah di atas, maka tujuan penelitian ini adalah untuk mengetahui validitas Rencana Pembelajaran Semester mata kuliah Kimia Dasar program studi Pendidikan Biologi Universitas Mahaputra Muhammad Yamin.

\section{METODE PENELITIAN}

Penelitian ini merupakan studi validasi. Akker (2013) menjelaskan bahwa dalam studi validasi, tujuan penelitian ini adalah pengembangan atau validasi teori, dan jenis penelitian ini didefinisikan sebagai studi intervensi pendidikan (seperti proses pembelajaran, lingkungan belajar, dan sejenisnya) dengan tujuan untuk mengembangkan atau memvalidasi teori tentang proses tersebut dan bagaimana caranya agar dapat dirancang.

Studi validasi terhadap Rencana Pembelajaran Semester mata kuliah Kimia Dasar didasarkan pada hasil diskusi serta pertimbangan pakar. Purwanto (2008) menjelaskan bahwa pengujian validitas dapat dilakukan menggunakan metode pertimbangan pakar/ahli. Pertimbangan pakar yang digunakan dalam validasi Rencana Pembelajaran Semester mata kuliah Kimia Dasar ini adalah pertimbangan dari 5 (lima) orang pakar di bidang pendidikan IPA. Pertimbangan pakar ini digunakan untuk mengetahui validitas isi dari Rencana Pembelajaran Semester mata kuliah Kimia Dasar yang sudah dirancang. Validitas isi yang dimaksud dalam penelitian ini adalah pengujian validitas yang dilakukan terhadap Rencana Pembelajaran Semester mata kuliah Kimia Dasar dari aspek format, isi, bahasa, tulisan, dan manfaat.

Instrumen yang digunakan dalam penelitian ini adalah angket validitas Rencana Pembelajaran Semester. Angket ini disusun dengan menggunakan skala Likert yang dimodifikasi menjadi 4 (empat) skala. 
Selanjutnya data angket dianalisis dengan mengunakan teknik analisis data deskriptif, yaitu mendeskripsikan validitas Rencana Pembelajaran Semester mata Kuliah Kimia Dasar. Rumus yang digunakan untuk menganalisis data adalah sebagai berikut:

$$
\%=\frac{\text { Skor perolehan }}{\text { Skor total }} \times 100 \%
$$

Selanjutnya penilaian validitas diberikan dengan kriteria sesuai Tabel 1, berikut ini:

Tabel 1. Kriteria Kevalidan Rencana Pembelajaran Semester Mata Kuliah Kimia Dasar

\begin{tabular}{|c|c|}
\hline Persentase & Kriteria \\
\hline $80 \%<\mathrm{P} \leq 100 \%$ & Sangat Valid \\
\hline $60 \%<\mathrm{P} \leq 80 \%$ & Valid \\
\hline $40 \%<\mathrm{P} \leq 60 \%$ & Cukup Valid \\
\hline $20 \%<\mathrm{P} \leq 40 \%$ & Kurang Valid \\
\hline $0 \%<\mathrm{P} \leq 20 \%$ & Tidak Valid \\
\hline
\end{tabular}

Sumber: dimodifikasi dari Eko (2012:123)

Selama proses validasi, pakar menggunakan instrumen yang peneliti susun sebagai acuan untuk menilai sejauhmana itemitem yang dirancang dapat mempresentasikan domain ukur yang dimaksud. Selanjutnya Shultz \& Whitney (2005) menjelaskan bahwa validitas isi dapat diukur dengan menggunakan CVR yang dikembangkan oleh Lawshe dengan rumus sebagai berikut:

$$
\begin{array}{ll}
\text { CVR }= & \frac{n_{e}-\frac{N}{2}}{\frac{N}{2}} \\
\text { CVR } & =\text { content validity ratio } \\
\mathrm{n}_{\mathrm{e}} & =\text { Jumlah pakar yang memberikan nilai } \\
& 3 \text { (relevan/layak) } \\
\mathrm{N} \quad= & \text { Jumlah semua pakar }
\end{array}
$$

Dalam pendekatan ini, seorang pakar diminta untuk menunjukkan apakah suatu item pengukuran dalam satu skala lainnya adalah "relevan/layak" sebagai bentuk operasionalisasi bangunan teori. Untuk mengukur CVR, 5 orang pakar diminta untuk memeriksa setiap item pengukuran validitas Rencana Pembelajaran Semester mata kuliah Kimia Dasar. Penskoran terdiri dari 3 (tiga) alternatif, yaitu 1 (tidak layak), 2 (kurang layak), dan 3 (layak).

Hendryadi (2017: 174) menjelaskan bahwa formula CVR ini menghasilkan nilai-nilai yang berkisar dari +1 sampai -1 , nilai positif menunjukkan bahwa setidaknya setengah panelis/pakar menilai relevan/layak. Semakin lebih besar CVR dari 0, maka semakin "relevan/layak" Rencana Pembelajaran Semester mata kuliah Kimia Dasar.

\section{HASIL DAN PEMBAHASAN}

Rencana Pembelajaran Semester ditetapkan dan dikembangkan oleh dosen secara mandiri atau kelompok bidang ilmu.yang sesuai dengan bidang ilmu pengetahuan dan teknologi dalam program studi. Rencana Pembelajaran Semester ini disusun menurut Peraturan Menteri Pendidikan dan Kebudayaan Nomor 49 tahun 2014 tentang Standar Nasional Pendidikan Tinggi, dan diperbaharui dengan Peraturan Menteri Riset, Teknologi, dan Pendidikan Tinggi Nomor 44 tahun 2015 tentang Standar Nasional Pendidikan Tinggi, menjelaskan bahwa Rencana Pembelajaran Semester paling sedikit memuat nama program studi, nama mata kuliah, kode mata kuliah, CPL, evaluasi, kemampuan akhir yang direncanakan pada setiap tahap pembelajaran, bahan kajian yang terkait dengan kemampuan yang ingin dicapai, metode pembelajaran, alokasi waktu, pengalaman belajar, kriteria, indikator, bobot penilaian dan referensi. Selanjutnya Kemenristekdikti (2017) juga menjelaskan hal yang serupa.

Berdasarkan kriteria tersebut, maka dirancanglah Rencana Pembelajaran Semester mata kuliah Kimia Dasar, dan hasil rancangan divalidasi untuk mengetahui tingkat kevalidannya. Validitas Rencana Pembelajaran Semester Kimia Dasar dilihat dari 4 (tiga) aspek, yaitu: format Rencana Pembelajaran Semester, isi, bahasa dan tulisan, dan manfaat Rencana Pembelajaran Semester. Hasil rekapitulasi data angket validasi Rencana Pembelaajaran Semester mata kuliah Kimia Dasar berdasarkan pendapat pakar, disajikan dalam Tabel 2.

Berdasarkan Tabel 2, dapat diketahui bahwa Rencana Pembelajaran Semester yang sudah dirancang, memiliki format, isi, bahasa, dan tulisan, serta manfaat yang sangat valid. Berdasarkan informasi pada kolom komentar dan saran pada lembaran validasi Rencana Pembelajaran Semester mata kuliah Kimia Dasar, maka dilakukan revisi. Saran revisi Rencana Pembelajaran Semester mata kuliah Kimia Dasar selengkapnya dapat dilihat pada Tabel 3. 
Tabel 2. Hasil Rekapitulasi Data Angket Validasi Rencana Pembelajaran Semester Mata Kuliah

\begin{tabular}{|c|c|c|c|c|}
\hline Aspek Yang Dinilai & Indikator Penilaian & $\begin{array}{c}\text { Rata- } \\
\text { rata }\end{array}$ & Persentase & Kategori \\
\hline \multirow[t]{2}{*}{$\begin{array}{lr}\text { Format } & \text { Rencana } \\
\text { Pembelajaran Semester }\end{array}$} & $\begin{array}{l}\text { Format Rencana Pembelajaran Semester } \\
\text { sesuai dengan KKNI }\end{array}$ & 3.6 & $90 \%$ & Sangat Valid \\
\hline & $\begin{array}{l}\text { Format Rencana Pembelajaran Semester } \\
\text { sederhana }\end{array}$ & 3.6 & $90 \%$ & Sangat Valid \\
\hline \multirow[t]{4}{*}{ Isi } & $\begin{array}{l}\text { Capaian pembelajaran mata kuliah } \\
\text { dirumuskan dengan jelas }\end{array}$ & 3.6 & $90 \%$ & Sangat Valid \\
\hline & $\begin{array}{l}\text { Terdapat sinkronisasi rumusan sub capaian } \\
\text { pembelajaran, indikator pembelajaran, } \\
\text { pengalaman belajar, serta materi pokok }\end{array}$ & 3.8 & $95 \%$ & Sangat Valid \\
\hline & $\begin{array}{l}\text { Materi pokok yang diberikan sesuai dengan } \\
\text { indikator penilaian }\end{array}$ & 3.4 & $85 \%$ & Sangat Valid \\
\hline & 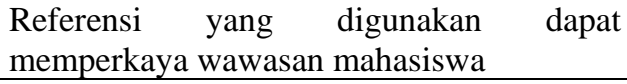 & 3.4 & $85 \%$ & Sangat Valid \\
\hline \multirow[t]{4}{*}{ Bahasa dan Tulisan } & $\begin{array}{l}\text { Menggunakan bahasa yang sesuai dengan } \\
\text { kaidah Bahasa Indonesia yang baku }\end{array}$ & 3.8 & $95 \%$ & Sangat Valid \\
\hline & Bahasa yang digunakan komunikatif & 3.8 & $95 \%$ & Sangat Valid \\
\hline & Bahasa mudah dimengerti & 3.6 & $90 \%$ & Sangat Valid \\
\hline & Tulisan mengikuti aturan EYD & 3.6 & $90 \%$ & Sangat Valid \\
\hline \multirow[t]{2}{*}{$\begin{array}{l}\text { Manfaat Rencana } \\
\text { Pembelajaran Semester }\end{array}$} & $\begin{array}{l}\text { Dapat digunakan sebagai pedoman } \\
\text { pelaksanaan pembelajaran }\end{array}$ & 3.6 & $90 \%$ & Sangat Valid \\
\hline & $\begin{array}{l}\text { Dapat digunakan sebagai indikator } \\
\text { keberhasilan proses pembelajaran }\end{array}$ & 3.4 & $85 \%$ & Sangat Valid \\
\hline
\end{tabular}

Sumber: Data Olahan Primer Tahun 2018

Tabel 3. Saran Revisi Rencana Pembelajaran Semester Mata Kuliah Kimia Dasar Berdasarkan Validasi Pakar

\begin{tabular}{|c|c|c|}
\hline $\begin{array}{c}\text { Aspek yang } \\
\text { Dinilai }\end{array}$ & Indikator & Saran Revisi \\
\hline $\begin{array}{l}\text { Format } \\
\text { Rencana } \\
\text { Pembelajaran } \\
\text { Semester }\end{array}$ & $\begin{array}{l}\text { Format Rencana } \\
\text { Pembelajaran } \\
\text { sesuai dengan } \\
\text { KKNI }\end{array}$ & $\begin{array}{l}\text { 1. Format Rencana Pembelajaran Semester disesuaikan dengan } \\
\text { format Rencana Pembelajaran Semester yang diberikan } \\
\text { dalam Panduan Penyusunan Perangkat dan Bahan Ajar dari } \\
\text { Kemenristekdikti. } \\
\text { 2. Alokasi waktu disesuaikan dengan minggu pertemuan. } \\
\text { 3. Instrumen penilaian dan evaluasi disesuaikan dengan } \\
\text { indikator yang diturunkan dari subcapaian mata kuliah. } \\
\text { 4. Bentuk/metoda penugasan lebih diperjelas. } \\
\text { 5. Sinkronisasi penggunaan simbol dan singkatan. } \\
\text { 6. Tambahkan capaian pembelajaran sikap, keterampilan } \\
\text { umum, keterampilan khusus, dan pengetahuan. }\end{array}$ \\
\hline Isi & $\begin{array}{l}\text { Capaian pembelajaran } \\
\text { mata kuliah } \\
\text { dirumuskan dengan } \\
\text { jelas }\end{array}$ & $\begin{array}{l}\text { Tambahkan capaian pembelajaran lulusan program studi, dan } \\
\text { lakukan perbaikan rumusan Sub Capaian Pembelajaran, Indikator } \\
\text { Pembelajaran, dan Materi Pokok. }\end{array}$ \\
\hline
\end{tabular}

Sumber: Data Olahan Primer Tahun 2018

Saran revisi dari pakar kemudian dibawa kedalam diskusi dengan rekan sejawat, maka dilakukan perbaikan terhadap Rencana Pembelajaran Semester mata kuliah Kimia Dasar. Berikut adalah hasil revisi terhadap rumusan Sub Capaian Pembelajaran, Indikator dan Materi Pokok terhadap Rencana
Pembelajaran Semester mata Kuliah Kimia Dasar.

1. Menjelaskan metode ilmiah, perubahan, penggolongan dan sifat materi serta pemisahan campuran. Indikator Pembelajaran:

a. Menjelaskan metode ilmiah. 
b. Membandingkan serta membedakan perubahan fisika dan perubahan kimia.

c. Membedakan unsur, senyawa, dan campuran.

d. Menjelaskan sifat materi.

e. Menjelaskan teknik pemisahan campuran.

Materi Pokok:

a. Metode Ilmiah

b. Perubahan Fisika dan Perubahan Kimia

c. Unsur, Senyawa, dan Campuran

d. Sifat Materi

e. Teknik Pemisahan Campuran

2. Menjelaskan hukum-hukum dasar kimia, teori atom Dalton dan hubungannya dengan hukum dasar kimia, massa atom dan massa molekul relatif, rumus molekul, rumus empiris, serta persamaan reaksi.

Indikator Pembelajaran:

a. Menjelaskan hukum-hukum dasar kimia.

b. Menjelaskan teori Atom Dalton dan hubungannya dengan hukum dasar kimia.

c. Menjelaskan massa atom dan massa molekul relatif serta cara penentuannya.

d. Menentukan rumus molekul dan rumus empiris.

e. Menyetarakan persamaan reaksi.

Materi Pokok:

a. Hukum Dasar Kimia

b. Hubungan Teori Atom Dalton dengan Hukum Dasar Kimia.

c. Massa Atom dan Massa Molekul Relatif

d. Rumus Molekul dan Rumus Empiris

e. Persamaan Reaksi

3. Menjelaskan Struktur Atom

Indikator Pembelajaran:

a. Menjelaskan sejarah perkembangan teori atom.

b. Menjelaskan penemuan dan sifat partikel dasar penyusun atom.

c. Menjelaskan dasar teori atom mekanika gelombang.

d. Menentukan konfigurasi elektron suatu unsur.

Materi Pokok:

a. Sejarah Perkembangan Teori Atom. b. Penemuan dan Sifat Partikel Dasar Penyusun Atom

c. Teori Atom Mekanika Gelombang

d. Konfigurasi Elektron

4. Menjelaskan perkembangan sistem periodik dan sifat keperiodikan unsur

Indikator Pembelajaran:

a. Menjelaskan sejarah perkembangan sistem periodik.

b. Menjelaskan sistem periodik modern serta golongan dan periode.

c. Menjelaskan sifat keperiodikan unsur

Materi Pokok:

a. Sejarah Perkembangan Sistem Periodik

b. Sistem Periodik Modern, serta Golongan dan Periode

c. Sifat Keperiodikan Unsur

5. Mendeskripsikan jenis-jenis ikatan kimia dan cara terbentuknya serta sifat-sifat senyawa yang terbentuk.

Indikator Pembelajaran:
a. Menjelaskan peranan elektron valensi dalam ikatan.
b. Menjelaskan ikatan ion serta cara
c. Menjelaskan ikatan kovalen serta cara terbentuknya dan sifat-sifat senyawanya.
d. Menjelaskan molekul polar.

Materi Pokok:
a. Elektron Valensi
b. Ikatan Ion
c. Ikatan Kovalen
d. Molekul Polar

6. Menjelaskan dan menerapkan konsep mol, kemolaran, dan perhitungan kimia.

Indikator Pembelajaran:

a. Menjelaskan konsep mol.

b. Menjelaskan kemolaran.

c. Menggunakan konsep mol dan kemolaran dalam perhitungan kimia.

Materi Pokok:
a. Konsep Mol
b. Kemolaran
c. Perhitungan Kimia

7. Menjelaskan konsep larutan serta jenisjenisnya, sifat fisika, sifat kimia, dan perhitungan dalam larutan tersebut. 
Indikator Pembelajaran:

a. Menjelaskan tentang campuran dan larutan.

b. Memahami tentang stoikiometri larutan.

c. Menjelaskan larutan elektrolit dan non elektrolit.

d. Menjelaskan larutan ideal dan hukum Raoult serta perhitungannya.

e. Menjelaskan sifat koligatif larutan.

f. Menjelaskan larutan asam dan basa, serta perhitungannya.

g. Menjelaskan tentang hidrolisis garam serta perhitungannya.

h. Menjelaskan tentang larutan buffer serta perhitungnnya.

Materi Pokok:

a. Campuran dan Larutan

b. Stoikiometri Larutan

c. Larutan Elektrolit dan Non-elektrolit

d. Larutan Ideal dan Hukum Raoult

e. Sifat Koligatif Larutan

f. Larutan Asam dan Basa

g. Hidrolisis Garam

h. Larutan Buffer

8. Menjelaskan jenis-jenis senyawa organik, kegunaannya serta reaksi-reaksinya dan polimer.

Indikator Pembelajaran:

a. Menjelaskan pengertian kimia organik

b. Menjelaskan kekhasan atom C.

c. Menjelaskan hidrokarbon, penggolongan, tatanama, sifat, isomer, dan reaksi-reaksinya.

d. Menjelaskan turunan alkana, penggolongan, tatanama, sifat, isomer, dan reaksi-reaksinya.

e. Menjelaskan tentang polimer.

Materi Pokok:

a. Pengertian Kimia Organik

b. Kekhasan Atom C

c. Hidrokarbon

d. Turunan Alkana

e. Polimer

Revisi juga dilakukan dalam merumuskan bobot penilaian untuk setiap sub-capaian pembelajaran. Berikut adalah bobot penilaian untuk setiap sub-capaian pembelajaran.

1. Menjelaskan metode ilmiah, perubahan, penggolongan dan sifat materi serta pemisahan campuran. (5\%)
2. Menjelaskan hukum-hukum dasar kimia, teori atom Dalton dan hubungannya dengan hukum dasar kimia, massa atom dan massa molekul relatif, rumus molekul, rumus empiris, serta persamaan reaksi. (10\%)

3. Menjelaskan Struktur Atom. (10\%)

4. Menjelaskan perkembangan sistem periodik dan sifat keperiodikan unsur. (10\%)

5. Mendeskripsikan jenis-jenis ikatan kimia dan cara terbentuknya serta sifat-sifat senyawa yang terbentuk. (10\%)

6. Menjelaskan dan menerapkan konsep mol, kemolaran, dan perhitungan kimia. (15\%)

7. Menjelaskan konsep larutan serta jenisjenisnya, sifat fisika, sifat kimia, dan perhitungan dalam larutan tersebut. (15\%)

8. Menjelaskan jenis-jenis senyawa organik, kegunaannya serta reaksi-reaksinya dan polimer. (10\%)

Revisi juga dilakukan dalam pada kriteria dan bobot penilaian untuk ranah kognitif, afektif dan psikomotor. Berdasarkan pertimbangan pakar dan merujuk pada pedoman penilaian yang berlaku di universitas maka kriteria penilaian dilakukan sebagai berikut:

Tugas dan latihan : :20\%

Partisipasi dalam kelas : $10 \%$

Quiz $: 10 \%$

Praktikum : $20 \%$

Ujian Tengah Semester : 20\%

Ujian Akhir Semester : 20\% (Kehadiran

minimal $\geq 80 \%$ )

Selanjutnya Rencana Pembelajaran Semester Mata Kuliah Kimia Dasar direvisi dan dibawa dalam diskusi bersama pakar. Berdasarkan pertimbangan pakar maka Rencana Pembelajaran Semester mata kuliah Kimia Dasar ini dinyatakan valid. Validitas diuji dengan menggunakan metode CVR. Hasil analisis ditunjukkan oleh data berikut ini:

$$
\begin{aligned}
& C V R=\frac{n_{e}-\frac{N}{2}}{\frac{N}{2}} \\
& C V R=\frac{5-\frac{5}{2}}{\frac{5}{2}} \\
& C V R=\frac{5-2.5}{2.5} \\
& C V R=1
\end{aligned}
$$


Skor CVR yang diperoleh bernilai +1 , ini menunjukkan bahwa Rencana Pembelajaran Semester mata kuliah Kimia Dasar yang dirancang relevan/layak dan bisa digunakan sebagai perangkat pembelajaran.

\section{KESIMPULAN}

Berdasarkan hasil analisis data dan validasi pakar, maka dapat disimpulkan bahwa Rencana Pembelajaran Semester mata kuliah Kimia Dasar sangat valid dan dapat digunakan untuk pelaksanaan perkuliahan.

\section{DAFTAR PUSTAKA}

Akker, Jan Van Den, et all. (2013). Educational Design Research (Part A: An Introduction). Enschede the Netherlands: SLO.

Eko Widiyoko. (2012). Teknik Penyusunan Instrumen Penelitian. Yogyakarta: Pustaka Pelajar.

Hendryadi. (Juni 2017). Validitas Isi: Tahap Awal Pengembangan Kuesioner. Jurnal Riset Manajemen dan Bisnis (JRMB) Fakultas Ekonomi Universitas Islam Attahiriyah, Vol 2 No. 2. Halaman 169178.

Kementerian Riset, Teknologi dan Pendidikan Tinggi. (2016). Panduan Penyusunan Kurikulum Pendidikan Tinggi. Jakarta, Indonesia: Kementerian Riset, Teknologi, dan Pendidikan Tinggi, Direktorat Jenderal Pembelajaran dan Kemahasiswaan, Direktorat Pembelajaran.

Kementerian Riset, Teknologi dan Pendidikan Tinggi. (2017). Panduan Penyusunan Perangkat Pembelajaran dan Bahan Ajar. Jakarta, Indonesia: Kementerian Riset, Teknologi, dan Pendidikan Tinggi, Direktorat Jenderal Pembelajaran dan Kemahasiswaan, Direktorat Pembelajaran.

Menteri Pendidikan dan Kebudayaan Republik Indonesia. (13 Juni 2013). Penerapan Kerangka Kualifikasi Nasional Indonesia Bidang Pendidikan Tinggi. Peraturan Menteri Pendidikan dan Kebudayaan Republik Indonesia Nomor 73 Tahun 2013. Jakarta, Jakarta, Indonesia: Menteri Hukum dan Hak Asasi Manusia Republik Indonesia.
Menteri Pendidikan dan Kebudayaan. (9 Juni 2014). Peraturan Menteri Pendidikan dan Kebudayaan Republik Indonesia Nomor 49 tahun 2014 tentang standar Nasional Pendidikan Tinggi. Jakarta, Indonesia: Kementerian Pendidikan dan Kebudayaan.

Menteri Riset, Teknologi, dan Pendidikan Tinggi Republik Indonesia. (28 Desember 2015). Standar Nasional Pendidikan Tinggi. Peraturan Menteri Riset, Teknologi, dan Pendidikan Tinggi Republik Indonesia Nomor 44 Tahun 2015. Jakarta, Jakarta, Indonesia: Kementerian Riset, Teknologi, dan Pendidikan Tinggi Republik Indonesia.

Presiden Republik Indonesia. (7 Mei 2013). Peraturan Pemerintah Nomor 32 tahun 2013 tentang perubahan Peraturan Peraturan Pemerintah Nomor 19 tahun 2005 tentang Standar Nasional Pendidikan. Jakarta, Indonesia: Kementerian Hukum dan Hak Asasi Manusia Republik Indonesia.

Presiden Republik Indonesia. (10 Agustus 2012). Pendidikan Tinggi. UndangUndang Nomor 12 Tahun 2012. Jakarta, Jakarta, Indonesia: Kementerian Sekretariat Negara Republik Indonesia. (Salinan)

Purwanto. (2008). Evaluasi Hasil Belajar. Surakarta: Pustaka Belajar.

Shultz, D. K. S., \& Whitney, D. J. (2005). Measurement Theory in Action: Case Studies and Exercises. Thousand Oaks: Sage Publications, Inc.

Syafruddin. (2017). Pengembangan Kurikulum dan Rencana Pembelajaran Semester (RPS) berbasis KKNI di Iperguruan Tinggi. Jurnal Al-Fikrah Volume 5 Nomor 1. Padang: Fakultas Tarbiyah dan Ilmu Keguruan, Universitas Islam Negeri Imam Bonjol. 